\title{
Financing of investment activities of Russian energy enterprises
}

\author{
Jamila Leontieva ${ }^{1,{ }^{*}}$, Ludmila Tarasova $^{2}$, Yulia Boiko $^{3}$, and Eugenia Zaugarova ${ }^{1}$ \\ ${ }^{1}$ Saint-Petersburg State University of Economics, Department of Accounting and Analysis, 191023, \\ Saint-Petersburg, Russia \\ ${ }^{2}$ Yanka Kupala State University of Grodno, Department of Finance and Accounting, 230023, Grodno, \\ Belarus \\ ${ }^{3}$ PJSC «Rosbank», 107078, Moscow, Russia
}

\begin{abstract}
The experience of the last decade in the formation of the existing structure of the national economy of Russia shows that in changing conditions, the relevance of reassessing the role of the fuel and energy complex (hereinafter - the FEC) in the foreign economic relations is growing in Russia. In addition, the FEC is of great importance for the Russian Federation not only from the point of view of foreign economic activity, but also from the point of view of the country's internal energy needs and the energy security of Russia as a whole, which necessitates a qualitative transformation, intensive development and diversification of this sphere. A key factor in the financial support of Russian energy companies is international leasing. The article presents the results of the study of legal, customs and tax aspects of regulating an international financial lease agreement (leasing), the current trends in leasing development.
\end{abstract}

\section{Introduction}

In 2011, the system of program documents of the Russian FEC was finalized, which includes, first of all, the Energy Strategy of Russia for the period up to 2030 (hereinafter ES-2030). EC-2030, approved by the order of the Government of the Russian Federation of November 13, 2009 No. 1715-r., defined the principles, strategic guidelines, main components and main mechanisms for implementing the state energy policy in accordance with the objectives and priorities of the country's development.

At the same time, the geopolitical crisis that began in 2014 and the introduction of financial and technological constraints against Russia by some countries, the changing dynamics of world energy prices, the acceleration of scientific and technological development and the beginning of a significantly more severe global competition for resources and markets, required the Ministry of Energy of the Russian Federation clarify and adjust by of priorities, tasks, implementation indicators and forecast scenarios adopted in ES-2030, which allows to ensure the ES-2030 to adapt to the realities of the post-crisis development of the world and Russian economies and energy.

*Corresponding author: $\underline{\text { ssu ea@mail.ru }}$ 
At the same time, the developers of the refined Energy Strategy (hereinafter - EC2035) note that the main external challenge for the Russian energy sector is to drastically increase competition in external energy markets, and the main internal challenge is the need for deep and comprehensive modernization of the Russian FEC, overcoming high wear of a significant part of infrastructure and production assets, technological lag of the Russian FEC from the level of developed countries.

It should be noted that in EC-2035, as well as in the subsequent EC-2050 Concept, the central idea is the transition from resource-based raw materials to resource-innovative development of the FEC. At the same time, the new role of the FEC in the country's economy will consist in the transition from the "development locomotive" to the "stimulating infrastructure", which will create conditions for the development of the Russian economy, including its diversification, the growth of the technological level, and the minimization of infrastructure constraints.

In the authors' view of ES-2035, the implementation of the target scenario will ensure the achievement of a number of key macroeconomic results, including achieving a phased increase in investment in the energy sector (oil complex, gas and coal industry, power industry, energy supply) from 460 billion dollars in 2011-2015 to 793 billion dollars in the years 2031-2035. Along with macroeconomic, other important results of the implementation of the Strategy are expected, including a decrease in the average depreciation of fixed production assets by 2035 by approximately $25 \%$ from the 2010 level.

Studies have shown that in the conditions of a slowdown in the growth of the Russian economy, the main priority is not a quantitative increase in the production volumes of the FEC, but a qualitative renewal (modernization) of the country's energy sector, which is associated with the implementation of large-scale investment projects.

According to the analytical center under the Government of the Russian Federation, in 2017, investments in the Russian economy showed a significant increase (over 4\%). More than $60 \%$ of the increase was due to the presence of the FEC, mainly in the oil and gas sector and pipelines. The problems of the investment process are much stronger in the electric power industry, especially in power generation: here investments have shrunk by more than $17 \%$ due to capacities (at least temporary) and the lack of new mechanisms to support investments.

Thus, in order to achieve the target parameters for the development of the FEC, it is necessary to ensure, first of all, "a sustainable attraction of investments in the power industry for the commissioning of new energy capacities, the withdrawal of obsolete and the modernization of existing generating equipment" [1]. In this regard, the issue of financing is central to the investment activities of energy companies, and the purpose of this study is to study and disclose the mechanism of international financial lease (leasing) as an effective form of international economic and investment cooperation between Russian energy enterprises.

\section{Materials and Methods}

According to a number of researchers, for a radical increase in the investment efficiency of the FEC, two coordinated groups of measures are required - innovation-technological and economic-organizational. The first is strategic in nature and requires long-term continuous exposure. The second group allows for quick and effective solutions, which are so necessary with the expected global turbulences. In the Russian FEC, the goal of economic and organizational measures should be, first of all, a radical reduction in the cost of investment projects and careful assessments of their economic efficiency and risks. It is necessary to rank investment projects in the energy sector with the refusal or delay of the implementation of the most economically inefficient, their strategic effect of the 
implementation is not completely clear. The second prerequisite for increasing efficiency and reducing the risks of investment projects of the Russian FEC is a radical improvement in the quality of state and especially corporate governance [2, p. 42].

Russian scientist and economist S.S. Chernov rightly notes that the particularities of the industry, which have a direct impact on the projects being implemented, determine the choice of sources of financing. So, specifically, the peculiarities of the electric power industry include:

1) the infrastructure nature of the industry;

2) the strategic importance of the industry (ensuring the national security of the state);

3) high capital intensity;

4) long implementation/ payback periods of the project due to the inclusion in the planning horizon of the useful life (20-40 years) of the most significant power equipment (besides the period of construction of the energy facility itself);

5) the complexity of calculating the discount rate, taking into account all the possible risks of the project;

6) the presence in the industry of a natural monopolist - the electric grid complex, which leads to the binding of the consumer to a particular supplier, the change of which is impractical because of the need for large capital investments for the construction and subsequent maintenance of specific objects;

7) risk diversification between the state and private investors according to the principle of asset ownership;

8) the recent transition to market relations in the energy sector (the need to find new sources of financing besides the budget);

9) the necessity to take into account when planning future development programs both for the Russian economy as a whole and for individual regions and industries;

10) the possibility of obtaining targeted investments from the budget for the implementation of priority projects, as well as the use of key indicators of government programs (projected values of energy consumption, inflation, etc.) in financial planning.

It is worth noting, that the most common sources of financing in the energy sector are: self-financing, direct investments, incorporation, investment loans, budget financing.

In modern conditions of reforming the Russian economy, associated with the necessity to intensify investment processes, including through the inflow of foreign capital, one of the main tools to modernize production, obtain financing for large projects with a large share of capital investments, as noted in the "Concept of development of the financial market of Russia until 2020", is a financial lease (leasing).

Thus, in the conditions of the sanctions development of the Russian economy and taking into account the reduction of the long-term lending market, international financial leasing can be considered as one of the most effective forms of international economic and investment cooperation.

Fundamental theoretical and organizational-economic provisions of leasing relations are reflected in the works of one of the leading Russian experts on leasing V.D. Gazman and etc., as well as in the basic research of the leasing relations of Western economists S.P. Amembal [3], P.F. Anderson [4], C. Drury [5], H.-J. Spittler [6], etc.

According to V.D. Gazman, when conducting leasing operations with energy assets, various types and schemes of leasing can be used, but, above all, traditional financial leasing, which provides for three main participants - the seller, the lessor and the lessee, and the conclusion of two main contracts - asset sales and leasing.

International leasing (classical leasing) of energy property connects three persons: the lessor, the lessee and the seller of the property (leased asset). The implementation of a foreign trade transaction is preceded by the conclusion of a contract between a resident (lessee) and a non-resident (lessor). To fulfill its obligations under an international financial 
lease (leasing) agreement, the parties enter into a purchase and sale agreement relating to binding agreements, as well as related agreements, for example, a fund raising agreement, a pledge agreement, etc.

It should be noted that the legal regulation of international financial leasing (leasing) is of fundamental importance for the organization of leasing operations in the foreign economic activity of Russian economic entities.

In order to identify differences in the international leasing agreement related to its legal regulation from the civil "internal" agreement of the same name, it is necessary first of all to determine under what conditions the leasing agreement becomes international.

The criterion of "internationality" of the contract is formulated in the UNIDROIT Convention on International Financial Leasing (1988) (hereinafter - the Convention) [7]. The Russian Federation joined the Convention in 1998 in connection with the adoption of the law on joining it. As in many other modern unifying international legal acts, in the Convention under consideration the criterion of "internationality" of a leasing agreement is the main place of business of partners located in different states. However, the Convention establishes a slightly different procedure for its own use, for example, from the UN Convention on Contracts for the International Sale of Goods (1980) [8].

In particular, the UN Convention recognizes possible and sufficient the use of one criterion - the location of commercial enterprises in different states, and in accordance with Art. 3 of the Convention, in addition to the similar criterion of location in different states of commercial enterprises of the lessor and lessee, additional requirements are established:

a) states of location of commercial enterprises of the lessor, lessee and supplier should be States parties to the Convention;

b) the supply contract and the lease agreement must be governed by the law of the State party to the Convention.

Therefore, if there is a general territorial condition: the commercial enterprises of the lessor and lessee must be located in different states, the Convention can be applied in the two cases mentioned.

The Federal Law of the Russian Federation "On Financial Lease (Leasing)" (further the Law on Leasing) (paragraph 3, clause 1, article 7) uses the category of "non-resident" as a criterion of "internationality" of a leasing agreement, which is not fully conforms to the provisions of the Convention.

From the review of the variants of the "internationality" criterion of the contract, including the leasing agreement, it is obvious that all of them contain a common feature an indication of the legal connection of the relationship with the legal orders of various states, the difference is only in the form of mediation and manifestation of such a connection.

The analysis of legislative and regulatory acts governing the international leasing agreement revealed the following features of its regulation:

1) In connection with the emergence of a legal relationship of a relationship under an international financial lease (leasing) agreement with the legal field of two states, the norms of various system membership are interacting: international (unified norms of the Convention) and national norms.

In addition to the above mentioned Law on Leasing, to national norms relates the Civil Code of the Russian Federation, which contains the rules governing the general provisions regarding leasing, as well as the rules of private international law governing relations between individuals and legal entities of different states. It should be noted that on the basis of paragraph 4 of Art. 15 of the Constitution of the Russian Federation, the norms of an international agreement are applied when an international agreement (in particular, the Convention) establishes other rules than those provided for by the legislation of the Russian Federation. Consequently, the UNIDROIT Convention on International Financial Leasing 
takes precedence over both the Civil Code of the Russian Federation and the Federal Law of the Russian Federation "On Financial Lease (Leasing)".

2) An interaction of the norms of national law of various sectoral affiliations occurs: civil law, private international law, other branches of public law: administrative law (first of all, its sub-sector such as customs law), financial law (especially its sub-sectors such as tax, currency law, as well as the rules governing settlement and payment relations).

3) The influence of legal sources of extra-legislative regulation takes place in here. First of all, to such sources it is necessary to include the general practice recognized as a rule of law (international customs) and lex mercatoria (international commercial law), which is commonly understood as the system of non-state regulation of foreign trade activities. The basis of lex mercatoria is the resolution-recommendations of international organizations on foreign trade issues, the Principles of International Commercial Contracts UNIDROIT 2004, as well as the International Rules for the Unified Interpretation of Trade Terms (INCOTERMS - 2010) developed by the International Chamber of Commerce.

The legal sources of extra-legislative regulation also include contractual regulation, which consists in special additional contractual terms that arise in the process of concluding and implementing an international leasing contract. So, in particular, the following conditions may be stipulated in the international leasing agreement: condition on applicable law, condition on customs payments, currency condition, condition related to payment, condition on the distribution of parties' responsibility for non-fulfillment of obligations. In addition, the contractual condition must determine the moment of transfer of ownership of the leased asset to the lessor and, at the same time, transfer of the right of ownership and use of the leased asset to the lessee.

4) The peculiarity of the legal regulation of an international leasing contract is determined by the form of the transaction, the written form of which is mandatory, which is established by the special conflict of laws rule of the Civil Code of the Russian Federation (clause 2 of Art. 1209), non-compliance with which invalidates the foreign trade transaction (clause 3 of Art. 162).

5) A special dispute resolution mechanism for obligations (arbitration clause) of the parties to an international leasing agreement. The peculiarity of such a mechanism is that the parties to the dispute themselves choose the law applicable to the arbitration procedure, and also choose in which language, in which arbitration and in which country the dispute will be considered.

Based on the analysis of the norms of the UNIDROIT Convention on International Financial Leasing, the following conclusions can be made about the characteristic features of financial leasing in accordance with the Convention:

1. The provisions of the Convention regulate only financial leasing transactions (classic tripartite leasing), leaving bilateral transactions outside of its scope of use (rent, leaseback).

2. The decisive role of the lessee is recognized, who is the initiator of the whole transaction, chooses the equipment, supplier and bears almost all the risks of the owner, not being such legally, i.e. emphasizes that "the active role of the user corresponds to the passive role of the lessor, whose participation in the transaction and the right of ownership are reduced to financing".

3. A financial leasing transaction is recognized as a single tripartite transaction, which testifies to the inseparable connection between the two contracts: the leasing agreement, which is assigned the main role in this relationship system, and the supply agreement.

4. Equipment under a financial lease agreement may be acquired by the lessor both before and after the conclusion of the lease agreement.

5. The term of the lease agreement should allow the lessor to return their investment in equipment, that is it should be approximately equal to the depreciation of equipment, which confirms the financial, and not any other, role of the lessor. 
6. Provision is made for variability in the issue of an option to purchase equipment, thus, the subsequent transfer of ownership to the lessee for leasing is not a mandatory characteristic of financial leasing.

7. The subject of leasing, in accordance with the Convention, is equipment (means of production).

8. Equipment is provided to the lessee for entrepreneurial (production and economic) purposes, and not for personal, family and household use purposes.

The legal regulation of relations in the field of customs in the Russian Federation from 01/01/2018 is carried out by the Customs Code of the Eurasian Economic Union (hereinafter - the CC EEU), replacing the Customs Code of the Customs Union (hereinafter - the CC CU), which was adopted in 2009. The new document provides for a transition to a single customs regulation in the framework of the Eurasian Economic Union, the agreement on the creation of which was signed at a meeting of the Supreme Eurasian Economic Council in Astana on May 29, 2014 and began to operate from January 1, 2015.

It should be noted that the CC EEU provides for a number of changes: simplification of customs operations; the introduction of electronic document management; priority of electronic customs declaration - declaration on paper will be allowed in exceptional cases; a new approach to regulating the status of an authorized economic operator.

According to the developers, the new document should bring customs legislation in line with law enforcement practice and the level of development of integration in the EEU and, most importantly, save market participants from unnecessary customs formalities and foreign economic activity costs.

According to some experts, the changes in the CC EEU are reduced to three main aspects:

1. The priority of electronic technology. Thus, according to the CC EEU, the main customs procedures should be carried out in electronic form, and paper documents only duplicate them.

2. Refusal to provide supporting documents to the customs authority, on the basis of which the electronic goods declaration was filled out.

3. Automatic release of goods. So, in particular, the possibility of performing customs operations related to the release of goods for free circulation or other statuses, according to the chosen and declared customs regime, exclusively by automatic information systems of customs authorities, is provided for. If the control system (risk profiles) detects errors, inconsistency of the declared information in different documents, discrepancies in the code of the Commodity Nomenclature for Foreign Economic Activities (further - CN FEA) of the goods and the calculation of customs value, the information system sends a request to the declarant.

In addition, the CC EEU provides all participants of foreign economic activity with the opportunity to take advantage of the delay in the payment of customs duties with interest.

In the CC EEU there is no independent categorization on the control of the customs value, but there are general provisions on control, with specific features of the control of the customs value. The basis of customs value control is a risk management system. If the risks are not identified, the automatic release of goods is made. When identifying a risk in which the actions of the customs authority to control the customs value depend on the analysis of documents, such documents can be gradually provided by the declarant at the request of the customs authority.

It should be noted that in the new CC EEU the basic principles are the same for all areas. Compared to the Customs Code of the Customs Union, there is no concept of "declaring" the customs value, based on the concept of "declaring goods".

Thus, from January 1, 2018, the CC EEU has no sections on decisions to be made on customs value as such (independent decisions), including the adjustment of customs value; 
there are no provisions on the declaration of customs value. Instead of the provisions on the adjustment of the customs value (Art. $68 \mathrm{CC} \mathrm{CU}$ ), the $\mathrm{CC}$ EEU established the procedure for preparing the following documents on introducing changes to the goods declaration regarding the change in the customs value:

- before the release of goods - the requirements for making changes (additions) to the goods declaration;

- after the release of goods - the decisions on making changes (additions) to the goods declaration.

According to the CC EEU, the basis for making amendments to the customs declaration in terms of information on the customs value are:

- before the release of goods - a statement of documented information not confirmed and not the elimination by the provided documents of the basis for the inspection of documents and information;

- after the release of goods - not the submission of any of the documents, details of which are indicated in the goods declaration; or submitted documents do not confirm the verifiable information.

In the development of the provisions of paragraph 3 of Art. 313 "Features of the customs control of the customs value of goods" CC EEU Board of the Eurasian Economic Commission approved the Regulation on the features of the customs control of the customs value of goods imported into the customs territory of the Eurasian Economic Union, which entered into force on May 2, 2018.

The peculiarity of the fulfillment of the obligation in terms of the supply of leased property under an international leasing agreement is related to its movement across the customs border of the States parties to the international leasing transaction, respectively, some actions are taken to bring the leased asset into the customs territory of the Union.

According to paragraph 1 of Art. 51 CC EEU goods that move across the customs border of the Union, are subject to customs duties and taxes. A full list of customs duties is given in paragraph 1 of Art. 46 CC EEU.

Customs duties and taxes are calculated in the currency of the Member State in which they are payable, except in cases provided for by international treaties within the Union and (or) bilateral international treaties of Member States when customs duties and taxes are calculated in another currency.

For the calculation of import customs duties, the rates of the Common Customs Tariff of the Eurasian Economic Union are applied. Documents for the calculation of customs payments are still a goods declaration and customs receipt order.

According to the current customs legislation, the size of the import tax on value added (VAT) and customs duty depends on two components: the customs value of the goods and the customs procedure.

The customs value of goods and (or) their physical characteristics in physical terms (quantity, weight, including taking into account the primary packaging of goods, which is inseparable from the goods before their consumption and (or) in which the goods are presented for retail sale, volume or other goods characteristics) is the basis for the calculation of customs duties (clause 2 of Art. 51 of CC EEU). The basis for calculating taxes is determined in accordance with the laws of the Member States.

The determination of the customs value of the imported goods is one of the most complex customs procedures. It should be noted that the customs value is determined based on the principle of the hierarchy of application of customs valuation methods: if the first valuation method is not possible to apply, then the second customs valuation method is used, etc. In total, the CC EEU proposed six methods of customs valuation, which duplicate the previously fixed and expired together with the Customs Code of the Customs Union: - at the value of the transaction with imported goods (Art. 39 of CC EEU); 
- at the value of a transaction with identical goods (Art. 41 of CC EEU);

- at the value of a transaction with similar goods (Art. 42 of CC EEU);

- subtraction method (Art. 43 of CC EEU);

- addition method (Art. 44 of CC EEU);

- reserve method (Art. 45 of CC EEU) [7].

However, not all methods are applicable to the goods supplied under international lease agreements. For example, it is not possible to determine the customs value of a leased property based on the value of the transaction with imported goods, since the leasing contract is not a purchase and sale agreement. Difficulties arise in determining the value of a transaction with an identical or homogeneous product, since it is obligatory to have information about the previously imported goods. Similarly, with the first method, being one of the instruments of an organization's investment policy, financial leases are not classified as property sales, and, therefore, the subtraction method cannot be used to calculate the value of the leased asset. As part of the calculation by the addition method, it is necessary to use accounting data, in respect of which business entities most often establish a trade secret regime. In this regard, the Federal Customs Service (FCS) of Russia recommends the use of the reserve method to determine the customs value of goods imported under international financial leases.

With reference to the world practice of applying the reserve method of customs valuation of the leased asset and documents of the World Customs Organization, as a basis for determining the customs value of goods the Federal Customs Service consistently recommends to use the following:

1. The value of the leased asset specified in the lease agreement, pro forma invoices, insurance contract and other shipping documents;

2. The list price of the goods or the price of the goods according to the catalog (with respect to the goods that were in use, the price of the new goods minus the amount of wear);

3. The value of the leased asset specified in the evaluation report of the object that meets the requirements of the legislation of the Russian Federation on valuation activities;

4. The amount of leasing payments calculated for the entire useful life of the leased asset provided that the transfer of ownership to the lessee is not provided;

5. Redemption price - provided that the redemption of the leased asset and the transfer of ownership of it to the lessee are provided for.

It should be noted that the customs value of the assessed (imported) goods does not include those expenses that are distinguished from the price actually paid or payable, declared by the declarant (customs representative), and are documented by him.

Currently, the main variety of possible options for the distribution of responsibilities for the delivery of goods from seller to buyer are described by the International Rules for the Unified Interpretation of Trade Terms (INCOTERMS-2010). Therefore, knowing the rules of INCOTERMS-2010, it is easy to navigate the structure of transportation costs, which must be added or deducted from the contractual (invoice) price of the imported goods.

It should be added that the provisions of Art. 48 of CC EEU established a broader concept of advance payments. It includes, in addition to export customs duties, taxes, customs duties and not identified by the payer in the context of specific types and amounts of export customs duties, as well as import and special, anti-dumping and countervailing duties.

CC EEU does not provide for a special customs procedure for customs clearance of items of international leasing, therefore, in accordance with Art. 127 CC EEU can be selected any of them. As a rule, if the lessor is a non-resident of the Russian Federation, then the lessee (or another person authorized by him) can place the imported leased property: 
1. Under the customs procedure "release for domestic consumption", there are no restrictions on the use and disposal of foreign leased items. This customs procedure involves a one-time payment by a person importing property, import customs duties and taxes, payment of special, anti-dumping, countervailing duties (according to the CC EEU), customs fees and appropriate for long-term leasing contracts with the subsequent acquisition of the leased asset.

2. Under the customs procedure "temporary importation (admission)", use and disposal of a foreign subject of leasing is limited to time. This customs procedure involves the conditional exemption (full or partial) from the payment of import customs duties and taxes. Thus, this procedure is preferential, since it provides for full or partial exemption from the payment of import customs duties and taxes, as well as provides an opportunity to postpone the payment of customs payments without charging interest and penalties.

It should be noted that the tenure of the leased property, if the leasing contract is not supplemented with the option of the final repurchase of the leased asset, in the territory of the Russian Federation or the EEU countries cannot exceed two years, which directly affects the permissible duration of the international financial lease agreement. According to A.S. Yachmeneva, this procedure allows not only to reduce the tax burden, but also to create an installment effect, since, in accordance with Art. 223 of the CC EEU import customs payments and taxes are payable monthly in the amount of 3\% of the amount that would be transferred to the budget by a business entity at the time of clearance of goods as released for domestic consumption.

The specificity of the normative regulation of tax collection when moving goods across the customs border of the Russian Federation is the fact that the procedure for tax collection is governed not only by the norms of Chapter 21 of the Tax Code of the Russian Federation (hereinafter - the TC RF), but also by the CC EEU, as well as by Federal Law of November 27, 2010, No. 311-FZ “On Customs Regulation in the Russian Federation".

Thus, based on the specifics of the normative regulation of the collection of "import" VAT, its particularity follows: "import" VAT is considered as a customs payment, and not as an indirect tax.

The object of taxation of "import" VAT is the importation of goods into the territory of the Russian Federation and other territories under its jurisdiction (subclause 4, clause 1, article 146 , chapter 21 of the TC RF).

Thus, if under the international leasing contract the lessor is a non-resident of the Russian Federation, then the algorithm for calculating the amount of "import" VAT when moving the leased asset to the customs territory of the Russian Federation can be represented as a formula:

The amount of "import"

$$
\mathrm{VAT}=(\mathrm{CV}+\mathrm{CD}+\mathrm{E}) \mathrm{x},
$$

where $(\mathrm{CV}+\mathrm{CD}+\mathrm{E})$ is the tax base, $\mathrm{CV}$ - the customs value of the imported leased asset; CD - the amount of import customs duties; E - the sum of the excise; R - VAT rate in percent, determined in accordance with the rules of Art. 164 of the TC RF.

The analysis of the norms of the TC RF regarding the peculiarities of taxation of goods imported into the territory of the Russian Federation allows us to state that the procedure for paying the "import" tax is made depending on the customs procedure in which the leased item is imported under an international leasing agreement:

1. Under the customs procedure "release for domestic consumption" - VAT is paid in full (subclause 1 clause 1 of article 151 of the TC RF);

2. Under the customs procedure "temporary importation (tolerance)", a full or partial exemption from VAT payment is possible (subclause 5 clause 1 of article 151 of the TC $\mathrm{RF})$. 
Thus, in all cases, "import" VAT is paid in a special order: not following the results of the tax period (a quarter) in which goods were imported into the territory of the Russian Federation, but as part of advance payments. Therefore, until the lessee, a resident of the Russian Federation, pays the import tax, the leased asset will not be issued by the customs authorities.

The right to apply the "import" VAT deduction arises from the importer when the following conditions are met:

1) purchased goods are used in taxable activities;

2) the goods are registered;

3) the amount of "import" VAT paid to the budget and there are supporting primary documents (Art. 172 of the TC RF).

One of the modern directions of development of leasing is the use of derivatives in leasing operations. So, for example, some cash flows under leasing agreements may change in the same way as cash flows from an independent derivative. In this case, we are talking about the fact that the derivative is embedded in the lease agreement, and the agreement itself is a hybrid one.

The types of leasing contracts with embedded derivatives encountered in practice are presented in the table below:

Table 1. The types of leasing contracts with embedded derivatives encountered in practice

\begin{tabular}{|l|l|lr|}
\hline \multicolumn{1}{|c|}{ Hybrid Contract } & \multicolumn{1}{|c|}{$\begin{array}{c}\text { Host } \\
\text { Contract }\end{array}$} & \multicolumn{1}{|c|}{ Embedded Derivative } \\
\hline $\begin{array}{l}\text { Operating lease agreement that provides for } \\
\text { inflation-indexed payments }\end{array}$ & $\begin{array}{l}\text { Operating } \\
\text { lease }\end{array}$ & $\begin{array}{l}\text { Payment determined with } \\
\text { reference to inflation-related } \\
\text { index }\end{array}$ \\
\hline $\begin{array}{l}\text { Operating lease agreement that provides for } \\
\text { payments in foreign currency }\end{array}$ & $\begin{array}{l}\text { Operating } \\
\text { lease }\end{array}$ & $\begin{array}{l}\text { Foreign exchange forward } \\
\text { contract }\end{array}$ \\
\hline $\begin{array}{l}\text { Operating lease agreement, according to } \\
\text { which rental payments depend on sales }\end{array}$ & $\begin{array}{l}\text { Operating } \\
\text { lease }\end{array}$ & Contingent rentals \\
\hline
\end{tabular}

Source: [9].

It should be noted that the embedded derivatives represent a great potential for increasing the efficiency of leasing operations on the basis of optimizing the cash flows of the lessee or lessor under the contract.

\section{Results}

In addition to the possibility of accepting deducting VAT international financial leases (leasing) has several other advantages:

- first, the minimum amount of investments at the investment stage;

- secondly, flexible lending requirements are a distinctive feature of financial leasing in comparison with conventional lending [10]. This is due to the fact that, unlike banks, leasing companies are not obliged to form reserves to secure their contracts;

- thirdly, the advantages stipulated by the current legislation of the Russian Federation, among them: the possibility of applying accelerated depreciation, which creates the effect of "delaying" the payment of income tax, as well as state support in the form of subsidies; payments under the leasing contract are fully charged to cost, which reduces the income tax. It should be borne in mind that in some cases, international leasing allows you to use the tax advantages provided for not only by Russian legislation, but also by the legal framework of the countries whose residents are other subjects of a leasing transaction; 
- fourthly, the possibility of transforming a leasing contract. By agreement of the parties involved in it, various aspects and conditions for the implementation of leasing services can be determined. For example, the schedule of payment of leasing payments is developed individually, taking into account the needs of the client, in addition there is the possibility of obtaining additional services for the maintenance of the leased asset or, as already noted, the possibility of additional delivery of equipment without having to enter into a new financial lease agreement. The contract may provide for the separation of the existing risks with reference to one or another business entity; accounting of the leased asset both on the balance sheet of the lessee and the lessor, the possibility of implementing the project on a turn-key basis from the development of a technical task to the transfer of a finished object put into operation.

\section{Discussion}

The issues of leasing energy equipment were discussed at the conference "Investment projects of the FEC. Aspects of financing investments and leasing of power equipment" held on 10/10/2014 at the 14th St. Petersburg International Energy Forum. According to the rapporteurs, until recently, the share of leasing in the oil and gas sector was insignificant and even for the largest companies was about $10 \%$, since only service companies used leasing, and the subject of leasing was the equipment that does not require complicated installation. In today's reality, leasing programs include project financing with equipment leasing. The existing problems were also noted: the leasing of complex energy equipment is often unattractive for leasing companies, since they are not ready to provide an individual approach to large-scale investment projects in the energy sector; the lack of definition of engineering in the Russian Federation as an official activity.

The considered advantages are often priorities not only when choosing a financial lease as a method of financing fixed assets by managers of an economic entity, but also in the case when international leasing is implemented by the organization as an investment policy tool. So, one of the successful examples of the implementation of the international leasing contract is the implementation of a transaction in the city of Chelyabinsk, as a result of which Siemens Finance LLC (hereinafter - the leasing company) for the Satkinsky Cast Iron Plant (hereinafter - SCIP), which is the leader in the Russian market of ferromanganese production and an exporter of these products on the world stage, has leased a turbocharger manufactured by Siemens Turbomachinery Equipment GmbH (Frankenthal, Germany), along with accessories. Start of project implementation - October 2014.

The choice of a leasing company was caused by the following reasons: first, at the time of purchasing equipment in Russia, turbochargers with a capacity of about $2 \mathrm{MW}$ were not produced - Russian factories produce them, as a rule, with a capacity of $30 \mathrm{MW}$ and above; secondly, the manufacturer provided full information on performance and managed to combine both the turbocharger of its own production and auxiliary equipment from its subcontractors in one offer, providing a factory warranty for the entire set of equipment supplied; thirdly, the reputation of the manufacturer of reliable equipment, the provision of many years of technical support and equipment maintenance even after the end of the warranty period.

According to the participants, the deal became a landmark for all parties for several reasons. One of the oldest enterprises in Russia, replacing an electric compressor with the most modern steam-driven turbocharger, is now paying leasing payments mostly due to savings in electricity costs.

\section{Conclusions}


Thus, our study showed that in the conditions of the economic crisis, the leasing tool can have a positive effect on stimulating investment demand and the country's economy as a whole. The increase in the number of leasing transactions and the expansion of their scale in the structure-forming industries (mining, energy, metallurgy, transport) contribute to the improvement of their technical equipment, the transition to innovative technologies, which ultimately leads to overcoming the existing imbalances in the economy. In turn, the use of fixed assets received in leasing allows a business to increase the supply and range of goods services. The relative availability of leasing in comparison with other ways of investing in fixed assets stimulates the growth of demand for the means of production, which leads to a multiplier effect and a chain reaction of the growth in demand for the products of many manufacturing and infrastructure industries. At the same time, new jobs are being created, the level of employment is growing. Thus, the intensification of leasing activity can have both direct and indirect effect on the development of the economy. The direct effect is to increase the actual tax revenues from the sale of goods and services to the budgets of all levels. As a result of the indirect effect, employment in industries is maintained, the production of competitive goods and services is increasing, product distribution channels are being developed, and the raw material orientation of national exports is being overcome.

\section{References}

1. Chebotarev, N.F. State energy policy in the fuel and energy sector: monograph / N.F. Chebotarev; Russian State University of Oil and Gas named after I.M. Gubkin. Moscow: Prospectus, 2018.

2. Energy of Russia: a post-strategic view for 50 years ahead: monograph / Bushuev V.V., Gromov A.I., Belogorev A.M., Mastepanov A.M. - M.: IAC "Energy”, 2016

3. Amembal, Halladay \& Isom, A Guide to Accounting for Leases, Salt Lake City, 1992.

4. Anderson, P.F.; and J.D. Martin. Lease vs. Purchase Decisions; A Survey of Current Practice. Financial Management, Spring 1977, P. 41-47.

5. Drury, C. and Braund, S. The leasing decision: a comparison of theory and practice // Accounting and Business Research, 1990. - № 20. - P. 91-179.

6. Spittler, H.-J. Practical leasing - trans. with german / H.-J. Spittler - M.: TSNIIEPselstroy, 1991

7. UNIDROIT Convention on International Financial Leasing, Ottawa, May 28, 1988. www.unidroit.org

8. United Nations Convention on Contracts for the International Sale of Goods, (UNITED NATIONS, New York, 2010).

9. Banka A., Deepika S. Embedded Derivatives: seemingly innocuous contracts under the microscope? // Bombey Chartered Accounting Journal, February 2010.

10. Kornilova, E.V. Financial design of leasing transactions: a monograph / under total. ed. L.G. Pashtova. - M.: Rusayns, 2015 